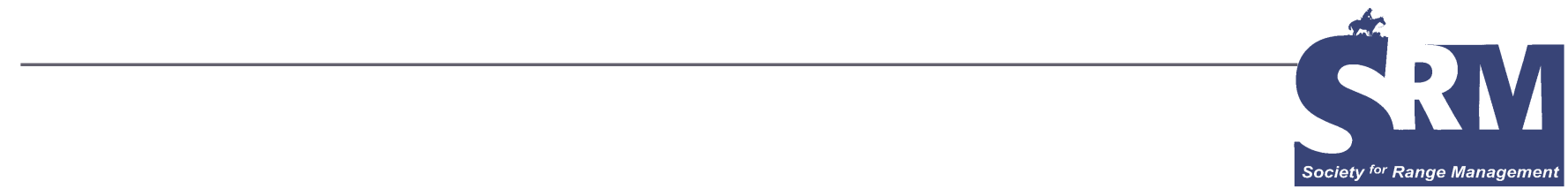

\title{
Exploring Kentucky in 2008
}

\section{From the rolling hills in the east to the beautiful lakes in the west, Kentucky has something for everyone. Kentucky is a state full of history and wonder, excitement and education. No matter what your interest, Kentucky can quench the thirst of any traveling enthusiast.}

\section{By Jennifer Johnson}

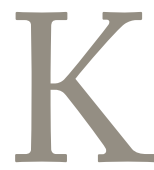

entucky, a state well known for being the horse capital of the world, came a long way throughout history. This land, originally noted as a hunting ground for Shawnee and Cherokee Indians, was not widely explored until the 1750s. After many treaties, the land was purchased from the Native Americans, and settlers began moving over the Appalachian Mountains and into the Cumberland Gap and Ohio River regions from Virginia, North Carolina, and Pennsylvania. One of the most famous explorers of this region, Daniel Boone, has been considered a founder of the state. At that time, settlers began introducing Kentucky to agricultural entities like tobacco, corn, and hemp. Kentucky's growth continued until the American Revolution, but because of ongoing violence in the region, there were fewer than 200 settlers in the area. After the Revolution, Kentucky County wanted to separate from Virginia. On June 1, 1792, Kentucky became the 15 th state added to the United States.

Kentucky may be known for its horses, horse parks, and bluegrass music, but it is also a state full of history. In the bluegrass region of the state, an area covering much of Lexington, Richmond, and Berea, we find a region once settled by Daniel Boone, rich with family tradition, and the birthplace of Bourbon. Kentucky is not only the birthplace of past presidents but also the birthplace of the "father of bluegrass" music, Bill Monroe. And what better to enjoy your bluegrass music than with some true Kentucky barbecue, found in the heart of Owensboro at Moonlite BarB-Q Inn, also the center of the much awaited for B-B-Q festival held each May.

For the explorer, Kentucky is a state perfect for adventure. Kentucky is home to one earth's natural creations, Mammoth Cave. Mammoth Cave National Park is a landmark worth exploring. From the vast caves to the everlasting trails, you could spend a lifetime amazed by the beauty that nature has created. With over 348 miles explored and mapped, Mammoth Cave is considered the longest recorded cave system in the world, with the National Park established to preserve the cave system, scenic river valleys, and parts of the hill country of south-central Kentucky. Mammoth Cave is a natural wonder open to the public year-round for all your exploring needs and is located only 90 miles south of Louisville.

Kentucky is a state rich with year-round attractions; from summer festivals to fall tours, there is always something to do. When visiting during the winter months, Louisville, Kentucky, is centrally located in a visitor's paradise, from downtown museums to expand your mind, to the new Fourth Street Live, known for its fun atmosphere, great food, and endless entertainment. If skiing the slopes is an adventure you crave, Paoli Peaks in Paoli, Indiana, is a mere 1.5-hour drive north from Louisville and has many 


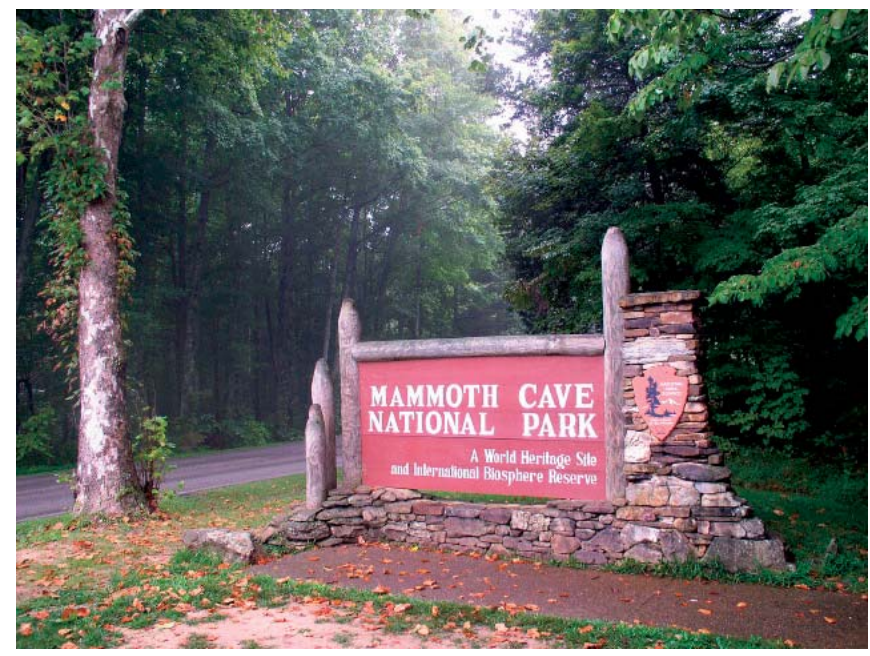

Mammoth Cave entrance.

opportunities for the skiing enthusiast. Whether you prefer daytime or nighttime skiing, this place has an option for everyone. For the prehistoric fanatic, a 10-minute drive can put you in the center of fossil heaven. Falls of the Ohio State Park, located on the river banks of the Ohio River just across from Louisville, is the home of one of the world's largest exposed fossil reefs from the Devonian Age. This wonder provides evidence that, more than 350 million years ago, an ocean once occupied the region that spreads from Louisville to Indianapolis.

Of course, if you visit Kentucky, there is often a desire to see the beautiful horse country that is Lexington. Just a short drive down I-64 and the beautiful countryside greets you with open arms. Lexington, Kentucky, is the home of numerous expansive horse farms throughout the area. A town full of history and wonder, Lexington is also the home of the Kentucky Horse Park, a major attraction for any visit. The Kentucky Horse Park, founded in 1978, is located on ground that has been the home of horses for more than 200 years. The park is dedicated to keeping alive the relationship between human and horse. An educational opportunity, the Kentucky Horse Park provides its visitors with the chance to see draft horses as they begin the day, participate in horse-drawn tours, and explore the Hall of Champions.

Kentucky is a state full of adventure and new beginnings. In Hodgenville, Kentucky, located an hour south of

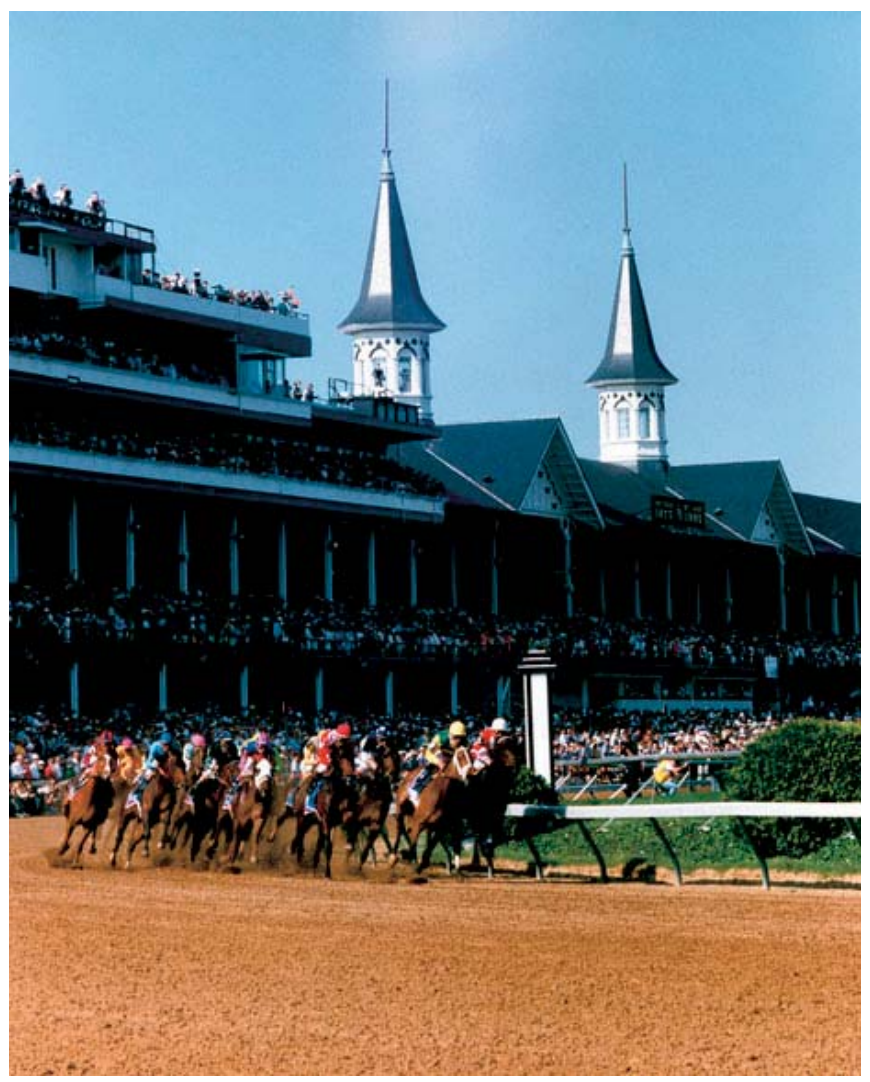

Churchill Downs.

Louisville, we find the birthplace of one of the great presidents, President Abraham Lincoln. Kentucky has served as the birthplace of many famous politicians, celebrities, and athletes, and Kentucky serves as the birthplace of the great American automobile. Bowling Green, Kentucky, is the home of the true sports car, the Chevrolet Corvette. The Corvette hit the automobile scene in 1953 and has been built exclusively in Bowling Green, Kentucky, for more than 55 years. Year-round, visitors drive into Bowling Green to tour the National Corvette Museum and to see just how these wonders were created and how they have evolved throughout the years.

Author is a Graduate Student, University of Kentucky, Lexington, KY 40508, jfj84@msn.com. 